\title{
色の標準化とその取り扱いについて
}

\author{
的日本色彩研究所 平 井 敏 夫

\section{Standardization for Colors and Color Control}

\author{
Toshio Hirai
}

Japan Color Research Institute

\section{1. まえがき}

エレクトロニクス技術のめざましい進展によって， 最近の测色器俄は多彩な機能を借えたものが多くなっ てきた。また，パーソナルコンピュータの普及も著し く，製品の色彩管理をするのには大変便利になったよ らに思われる。

しかし、てれらの機能を使い分けて，十分に活用す るためには，测色器械が計測しているデータの意味を よく理解しておく必要がある。色を計量的に管理する とはいっても，製品の色は最終的には，人の目によっ て見られるものであるから，測色值はあくまでも色を 製造していく過程における管理手段に使うべきものな のである。測色值に頼り過きると，目をつぶって色を 見ているよらなことにもなりかねない。

色は誰でもが自由に見ることができ，見ることによ って，すぐに理解できる。それが「色」なのである。 しかし，色の見かたを棒隼化することによって，色の 見え方を定め，二れによって色を数值的に扱いらるの であり，また，それを前提にして測色器械を人の代わ りにして，色彩管理に活用できるのである。

そこで，色を標隼化する手続きとその取り扱いにつ いて述ぺる。

\section{2. 色を見る条件}

\section{1 色の見え方}

色は暗やみでは見えない。目を閉じてもみることは できない。また，見る物体が視界になければ見ること はできない。色は光と物体と目の関璉で熟められる視 覚の現象である。

色が認められるまでの過程は図111に示すように， 光源から放射された光が物体に当たり，そこで反射あ るいは透過した光が目に入る。その光は目の網朕を刺

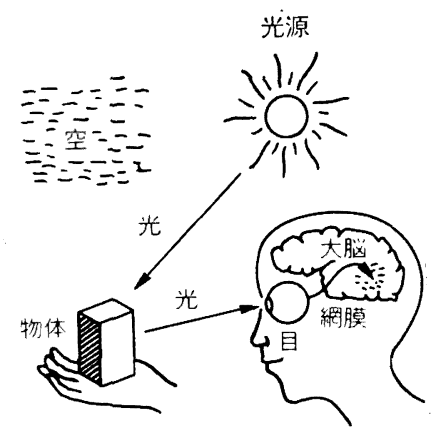

Fig. 1 The processes of color vision.

激して，これによって生じた視神経の活動が大脳に伝 えられて，そこで色の感覚が生ずる。そして物体の色 として恋識されるのである。こらして見える色を物体 色といら。また，物体色には表面色と透過色との区別 がある。前者は物体から反射した光によって生ずる色 であり，後者は物体を透過した光によって生ずる色で ある。

また，目を光源に向けると光源から放射された光が 直接目に入る。その光によって生ずる色は, 光源の色 として悲識される。こうして見光る色を光源色といら。 われわれが見ている色はこのらちのいずれかである。 しかし，日頃の生活の中で色を見るとき，このような 認識過程を意識して見ていない。視線を向けて物を見 る。そこに「色の付いた物がある」と思って見ている。 また，色が照明や見方の違いによって異なって見えた りすることも知っている。例壳ば，「同じ色」でも異 なった照明のもとで見ると違った色に見えるし，弾色 で塗られた箱の絵を画くとき，箱の 3 方の面を湍淡を 変兄て色を塗り分ける。 3 方の面が同じ色であっても それぞれの面の色の見え方が暹うことを知っているか 
らである。

物体の色を「この色だ」と定めるには，その物体が いつでも，どこでも，だれにでも同じ色に見えるよう にしておかなければならない。つまり，客観的に色を 見る方法を決めておく必要がある。

\section{2 照明方法}

そのためには，まず照明のあり方を整えておかなけ ればならない。照明のあり方を決める主な要因は光源 から出る光の質, 強さ，方向である。照明関係の国際 的に標準化を図る審議機関として，国際照明委員会 (Commission Internationale de l'Eclairage : 略称 CIE) がある。その CIE で「標準の光」を定めた。 標準の光には $\mathrm{A} ， \mathrm{C} ， \mathrm{D}_{65}$ などが定められていて，そ のなかでも色を見るための照明光源として，標準の光

$\mathrm{D}_{65}$ を基準にしている。

標準の光 $\mathrm{D}_{65}$ は，色温度が約 $6500 \mathrm{~K}$ の紫外波長域 を含む平均的な昼光を意味する。自然昼光は時々刻々 と変わっていくが，これを数多く実測し統計的手法で 処理して，各々の色温度に打ける昼光の代表を定めた。 このよらにして，CIE が規定した光を CIE 昼光とい い, 種々の色温度における昼光が規定されている。

標準の光Cは，可視波長域の平均的な昼光で代表さ れる光であるか゚，本来は標準の光 A（タングステン電 球の光)にDGフィルターをかけて，色温度を約 6774 Kに点灯して得られる人工光である。DG フィルター は R. Davis と S. Gibson が考案した 2 層の溶液つ イルターである。

図 2 にこらの標準の光の分光分布の例を示す。

\section{3 箱察方法}

われわれは目から，物の形状，色，質感，あるいは， 大ささ，位置，周りの状況……なとささざまな視覚情

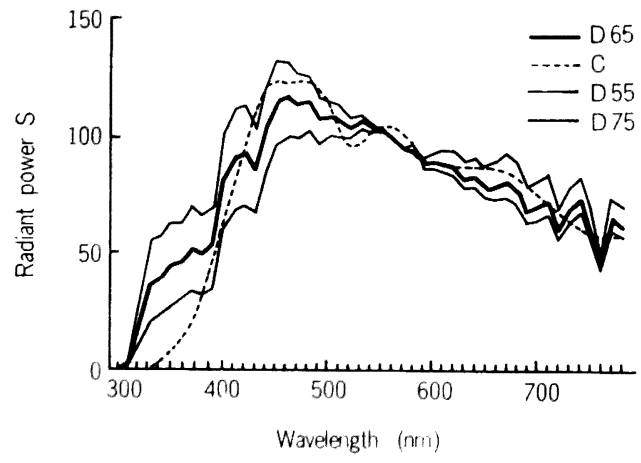

Fig. 2 Relative spectral power distributions of CIE standard illuminants $\mathrm{C}, \mathrm{D}_{55}$, $\mathrm{D}_{65}$ and $\mathrm{D}_{75}$.
報を得て，その物についてのさまざまな印象や感情を いたいたり，連想したりして行動に結びつけて生活し ている。

ところで，照明の環境が整ったとしても，色は見る 状況によって違った見え方をすることもある。

例えば，インテリア デザインなどで，色見本を見 て決めた色が実際の壁面に塗り上がったとき, 明るく 派手に見えてしまらことがある。このような現象を色 の面積效果という。一般に面積の大きい色は小さい面 に比べて明るく，彩度が高く見える傾向がある。従っ て，同じ大きさの面で比較する必要がある。

2 つの色が相互に影響し，その相違が強調されて見 える現象を色対比といら。強調のされかたによって， それぞれ色相対比, 明度対比, 彩度対比などの種類が ある。例えば，ある色を暗い背景に置くと明るい色に 見光，明るい背景に置くと暗い色に見える。また，あ る色を彩度の高い背景に固くとくすんた色に見え，彩 度の低い背景に㯰くとあざやかな色に見える。だから 色を見るときは背景を整えておかなければならない。

半つやの表面の色や透明感のある色，金属感のある 色などは，それを見る角度のわずかな差によって明る く埲いて見えたり，暗い色に見えたりする。それゆえ， 色を見るときの方向を決めておかなければならない。

\section{4 色の比較方法}

以上の例のように，照明の方法や観察の仕方によっ て色の見え方が違らので，色の観察条件を標準化して おく必要がある。その規格が JIS Z 8723 (表面色の 比較方法）である。次にその要約を述べるが，規格の 詳細については JIS を参照されたい。

(1) 適用範囲

この方法は表面色の比較に用いる。たたし，完全鏡 面や鏡面に近い面には適用しない。

(2) 照明光源

照明に用いる光源は，標準の光 $\mathrm{D}_{65}$ かこれに準ずる 光源*)を用いる。

(3) 作業面照度

色を比較する作業面の照度は500ルクス $(l x)$ 以上

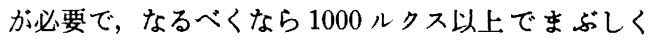
ない程度の照度籁囲で，かつ均等な照明が望ましい。

\section{(4) 照明と観察方向}

$45^{\circ}$ 方向からの照明では真上から観察し，真上から の照明では $45^{\circ}$ 方向から観察する。また，あらゆる方 向から均等に照明されているときは，真上または $45^{\circ}$ 方向から観察する。

（5）配 圆

比較する色は互いに隣接して並べ，色の面が同一の 
平面に並ぶように配直する。

(6) 背景の調整

色の周囲を整え，色の大きさを同じするためにマ スクを用いる。マスクの表面は光沢や蛍光がなく，均 質な無彩色とする。無彩色の明るさは比較する色の明 度に近いものがよい。

(7) 色の面の大ささ

比較する色の面の大きさは視角で $2^{\circ}$ 以上とする。

(8) 観察者

正常な色覚を有する者であること。

*)：例之ば，北空昼光，標準照明装置あるいは演 色性のよい光源など。

\section{3. 色の測定}

\subsection{CIE の表色方法}

以上に述べた色の認識されるまでの過堹から分かる ように，物体の色は照明する光源の質，光に対する物 体の反射特性及び光に対する目の感度によって決まる ので，市らかじめ光源の分光分布と目の分光感度（等 色関数とい5。図3を参照）を規定して沏けば，色は

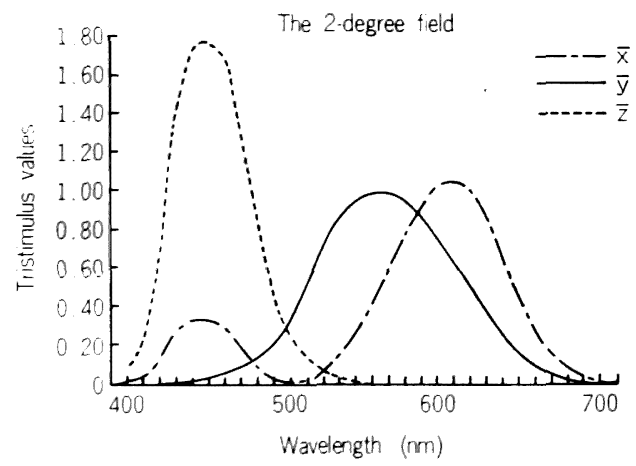

Fig. 3 The CIE 1931 standard color matching functions.

その物体の分光反射率のあり方によって決まる。CIE はこうした考え方で色を表示する方法を標準化した。

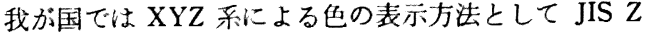
8701 に制定されており，研究分野のみならず企業で の色彩管理や調色管理などに広く使われている。

この方法の色表示の形式は，(1)式によって計算され た 3 つ値X，Y，Zで色を表示する。このX，Y， Zの值を色の三刺激值といら。

$$
\begin{aligned}
& \mathrm{X}=\mathrm{K} \int \mathrm{S}(\lambda) \mathrm{R}(\lambda) \overline{\mathrm{x}}(\lambda) \mathrm{d} \lambda \\
& \mathrm{Y}=\mathrm{K} \int \mathrm{S}(\lambda) \mathrm{R}(\lambda) \overline{\mathrm{y}}(\lambda) \mathrm{d} \lambda \\
& \mathrm{Z}=\mathrm{K} \int \mathrm{S}(\lambda) \mathrm{R}(\lambda) \overline{\mathbf{z}}(\lambda) \mathrm{d} \lambda
\end{aligned}
$$

ここで， $S(\lambda)$ は照明に用いた標準の光の分光分布， $\mathrm{R}(\lambda)$ は物体の分光反射率, $\overline{\mathbf{x}}(\lambda), \overline{\mathrm{y}}(\lambda), \overline{\mathbf{z}}(\lambda)$ は等色 関数，Kは $1 / \int \mathrm{S}(\lambda) \overline{\mathbf{y}}(\lambda) \mathrm{d} \lambda$ で与えられる定数である。 (1)式の意味は，標準の光の下で，ある物体を観測者 が見たときの色の感覚を 3 つの数值に置き换光て表現

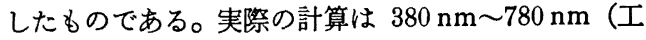
業的炕は $400 \mathrm{~nm} \sim 700 \mathrm{~nm}$ ) の範囲を $5 \mathrm{~nm}, 10 \mathrm{~nm}$ あるいは $20 \mathrm{~nm}$ の間隔で各波長ごとに掛け算し，そ れを総計して求める。図4 亿計算手順例を示す。

また，標準の光の分光分布，等色関数及び定数 $\mathrm{K}$ 既知の値なので，あらかじめこれを乗算した数表（重 価係数表といら。）が用意されていて，普通これを使 5 。

色をX，Y，Zの值で表すことができると，これら を座標軸にして色の位置を 3 次元の座標系で図示する ことができる。

\subsection{UCS の表色方法}

物体の色がどんな色であるかを絶対值的に決めるこ とも重要であるが，製品の色彩管理をする場合，標準 色に対して陚料色がどういう位置にあるのか，陚料色 がどら違らのか，標準色と差がないといえるのか等々 を知りたいことの方が多い。

三刺激値は色を空間座標で表示しているのだから， 2 つの色の差（色差）はそれぞれの色の座膘間の距離 で数量的に表すことができる。しかし，その幾何学的 距離（計測量）と色美の見兄（感覚量）との間に対応 がないと実用性に乏しい。事実，CIEの表色系は表面 色の色差管理に向かないのである。

色を表示するための座標系は数多くあるが，色差の 量を表すのに都合よく作られた色の來標系をUCS〔均 等色空間 (uniform color space)]という。

長年にわたり色差の研究がなされ，いろいろなUCS や色差計算の公式が提案され，実用もされてきたが標 準化といら立場から，国際的に統一した色差の表示方 法を規定することが望まれたため，CIEでは提案され てきた種々の UCS や色差計算公式について検討をし

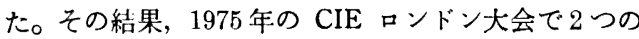
UCS と色差計算方法を採択し， CIE (1976) 勧告と して発表した。これを受けて，ISO (国際標準化機構) をはじめ各国での規格の見直しがなされた。

次に，その UCS と色差計算式の概略を示す。詳細 は JIS Z 8730 （色差表示方法）を参照されたい。

1） L*a*b* 表色系及び色差公式

E. Q. Adams（1942）が提案した $\mathrm{V}_{\mathrm{x}} \mathrm{V}_{\mathrm{y}} \mathrm{V}_{\mathrm{z}}$ 表色系 に近似させ，式を简略にした UCS で(2)式によって定 義される数值で表す。 
物体色（あざやかな赤）

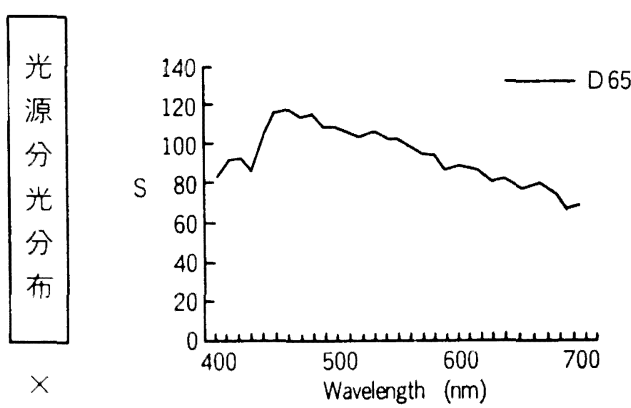

\begin{tabular}{|l|}
\hline 分 \\
光 \\
反 \\
射 \\
\hline
\end{tabular}

$x$

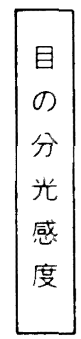

II
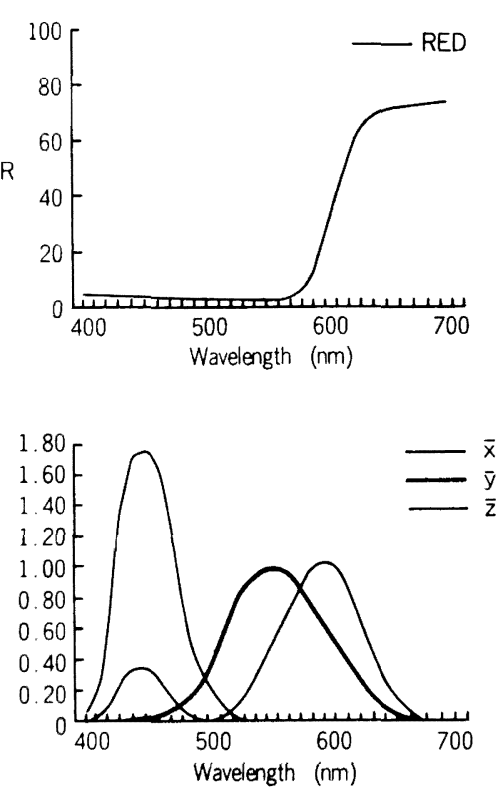

物体色（うすい青）
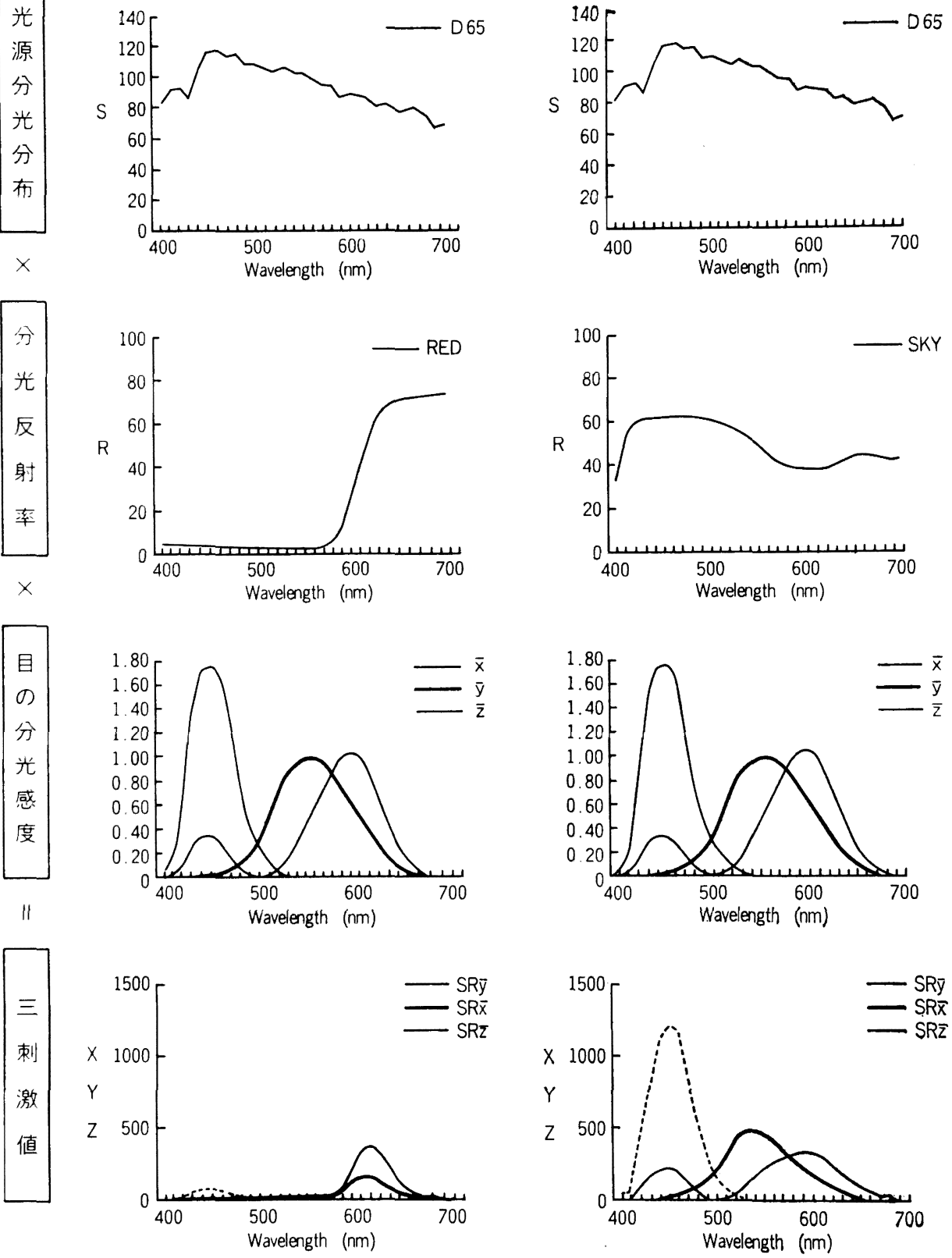

Fig. 4 The way in which the CIE tristimulus values $\mathrm{X}, \mathrm{Y}$ and $\mathrm{Z}$ of a color are obtained 


$$
\begin{aligned}
& \mathrm{L}^{*}=116\left(\mathrm{Y} / \mathrm{Y}_{\mathrm{n}}\right)^{1 / 3}-16 \\
& \mathrm{a}^{*}=500\left[\left(\mathrm{X} / \mathrm{X}_{\mathrm{n}}\right)^{1 \cdot 3}-\left(\mathrm{Y} / \mathrm{Y}_{\mathrm{n}}\right)^{1 / 3}\right] \\
& \mathrm{b}^{*}=200\left[\left(\mathrm{Y} / \mathrm{Y}_{\mathrm{n}}\right)^{1 / 3}-\left(\mathrm{Z} / \mathrm{Z}_{\mathrm{n}}\right)^{1 / 3}\right]
\end{aligned}
$$

ここで， $X_{n}, Y_{n}, Z_{n}$ は照明に用いた植隻の光の三 刺激值，X，Y，Zは対象としている物体色の三刺激 値である。

色差計算は(3)式による。

$$
J \mathrm{E}^{*}=\left[\left(J \mathrm{~L}^{*}\right)^{2}+\left(J \mathrm{a}^{*}\right)^{2}+\left(J \mathrm{~b}^{*}\right)^{2}\right]^{1 / 2}
$$

2） L*u*v* 表色系及び色差公式

CIE が 1964 年に暫定的に提案した $U^{*} V^{*} W^{*}$ 表色 系を修正したUCS で、(4)及び(5)式によって定義され る数値で表す。

$$
\begin{aligned}
\mathrm{L}^{*} & =116\left(\mathrm{Y} / \mathrm{Y}_{\mathrm{n}}\right)^{1 / 3}-16 \\
\mathrm{u}^{*} & =13 \mathrm{~L}^{*}\left(\mathrm{u}^{\prime}-\mathrm{u}_{\mathrm{n}}^{\prime}\right) \\
\mathrm{v}^{*} & =13 \mathrm{~L}^{*}\left(\mathrm{v}^{\prime}-\mathrm{v}^{\prime}{ }_{\mathrm{n}}\right) \\
\mathrm{u}^{\prime} & =4 \mathrm{Y}^{\prime}(\mathrm{X}+15 \mathrm{Y}+3 \mathrm{Z}) \\
\mathrm{v}^{\prime} & \left.=9 \mathrm{Y}^{\prime} / \mathrm{X}+15 \mathrm{Y}+3 Z\right) \\
\mathrm{u}^{\prime} & =4 \mathrm{Y}_{\mathrm{n}}\left(\mathrm{X}_{\mathrm{n}}+15 \mathrm{Y}_{\mathrm{n}}+3 Z_{\mathrm{n}}\right) \\
\mathrm{v}^{\prime}{ }_{\mathrm{n}} & =9 \mathrm{Y}_{\mathrm{n}}\left(\mathrm{X}_{\mathrm{n}}+15 \mathrm{Y}_{\mathrm{n}}+3 Z_{\mathrm{n}}\right)
\end{aligned}
$$

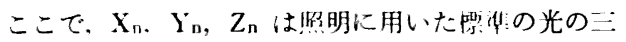
刺激値，X，Y：Zは対象としている物体色の三刺激 値である。

化差部算は6式による。

$$
\left.J \mathrm{E}^{*}=\left(J \mathrm{~L}^{*}\right)^{2}+\left(\mathrm{Ju}^{*}\right)^{2}+\left(\mathrm{V}^{*}\right)^{2}\right]^{1 / 2}
$$

我が国でき1978 年に JIS を見直して，1980年に改 正された規格票が刊行された。JIS では上記の CIE 勧告の UCS のほか心，工業界の事情を考虑して，\| 規格にある色差表示方法我併記し，当分の間，昍規格 にある色差表示の方法す残すことにしてあるが，現在 市肘されている槽隼的な湘色器械のほとんとはされら に対応できるよらに作られている。なお，通常の色彩 管理には L*a*b* 表色系が使われる。

\section{3 色の則定方法}

色を測定する方法は目視比較方法, 温台等色方法, 测激值百読方法, 分光測色方法の 4 種類に大別される。 目視比較方法と混合等色方法は，体手つけられた色の スケールと試料とを目視によって比較し評洒する方法: である。目視比㜞方法で物体色搝準に使用するスケー ルには，例えは，JIS 標隼色票（JIS Z 8721 保拠） があり，それに揭载されている色票と陚料色とを比較 し，也票に付けられている三属性の記号（色相, 明度, 彩度）で表示する。目視評価を行ら埸合は, JIS Z
8723 に規定された色の此校条件の下で行うことが大 切である。

刺激值直読方法や分光測色方法は JIS Z 8722 (物 体色の測定方法）など規定されている条件に準拠し て作られた測色器械を使って，色を計量的に評优する 方法である。現在の色彩管理に活用されている、業们 測では分光測色方法が主流を占めているようである。 分光測色方法は武料色の分光反射涪（又は分光透過 卒)を測定し，規定さ机た方法で計算処理を行い， CIE 表小やUCS な゙休系化されている色空間の坐噄 を求める方法である。

次に，测色に関して規定されている諸条件の概要を 小す。

(1) 光学:系の種類

方法 a ) 2 光路光学系

方法 b ) 1 光路光学系

(2) 照明受光条件の種類

条件 a ) $45^{\prime}$ 照明， $0^{\circ}$ 受光

条件 b ) $0^{\circ}$ 照明, $45^{\circ}$ 受光

条件 c ） d （又はD）照明, $0^{\circ}$ 受光

条件 d ) $0^{\circ}$ 照明, d (又はD) 受光

(3) 計算用照明光の種類
摽準の光
i ) $\mathrm{A}$
ii) $\mathrm{D}_{6 \overline{5}}$
iii) $\mathrm{C}$
補助㯲集の光
i) $\mathrm{D}_{50}$
ii) $\mathrm{D}_{55}$
iii) $D_{75}$ 等
武料光
i ) $\mathrm{F}_{6}$
ii) $\mathrm{F}_{8}$
iii) $F_{10}$ 等

(4) 等出网数の種類

条件 1) $2 \circ$ 視野条件にお汁等色関数

条件さ） $10^{\circ}$ 視野条件にお枚等色関数

(5) 重価係数の種類

$5 \mathrm{~nm}$ 間隔の重他係数による訃算方法:

$10 \mathrm{~nm}$ 間隔の重価係数による部算方法

$20 \mathrm{~nm}$ 間隔の重価係数による計算方法

このよらに測色条件にはいろいろな種類があるので 測定する場合，これらの条件のどれであるかを明確に しておく必要がある。

〔例〕 1 光路光学录，条俳: d ), $\mathrm{D}_{65}$, 条件 1 ), $20 \mathrm{~nm}$ 間隔の重価係数による測色条件。

\section{4. メタメリズムとその評価}

1 枚の色紙を半分に切って，これを並べて見ると同 じ色に見える。当然，色忉も同質である。また，ある 色と等しく見える巴出を，別の色材の䍡色で作ることも でさる。例えば，オレンジ色は崩と赤との混色でもで きるし，緑は黄と青とで俳ることができる。

前者のように同質の色対の関係にある也をアインメ リズム（isomerism）といい，後者のよらな関係にあ 
る巴をメタメリズム (metamerism) という。

アイソメリズムの関俰にあるせせ分光分价が同質な ので，どんな黇明の下で胃ても「同じ色」に見える。 メタメリズムの関係にある色は特定の照明の下では視 覚的に等しく見えても，分光分仰が異なるために，別 の照明の下では違った色に見えることがある。図5に メタメリズムの関係にある色対の例を示す。

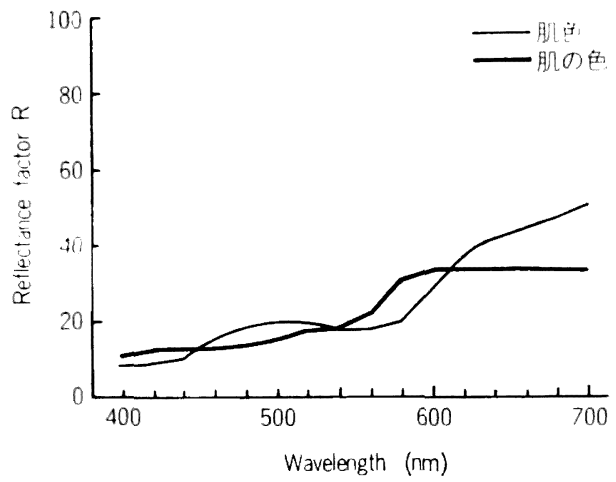

Fig. 5 Examples of metameric objects.

一般に，色の比較作業は北空尽光や標準照明装置の 下で行われる。この場合，おおよその巴を指小するた めに与えられた色見本との比較であったり，初めて作 る巴であるならば，前記比色方法で合格しているか否 かを判定しても問題は起こらない。しかし，標準の色 が将来, 製品として組子台わされる部品を代表する仙 見本であったり，また，過去に製造したことのある製 品のロットを代表する見本であるときは汒俧をする必 要がある。その理由は，ユーザー側で製品同士を並置 して見比べることが多いので，著しいメタメリズムの 現象が起きていると毕造いのクレームになることがあ るからである。その对策として，標準照明装洕の下で 比色をするとともに，ちら一つ別の照明，例えば電登 光の下で比色を行い，両方の照明において色差の少な いことを確跑しておくようにする。

月標色と武料巴との間で，人タメリズムがどの程媛 発生するかを定量的に予测でされば調色作整や色众乍 作紫をする上で郎公がよい。

メタメリズムの伻価法の JIS は 1984 年に制定さ れた。その方法の䣷略はつきのとおりである。

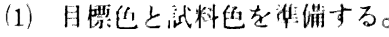

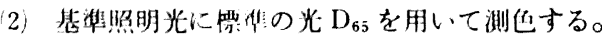

3) 武駼照明光に临: 焦の光Aを用いて测色する。

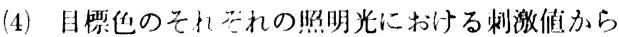
補正係数を計算し，试料也の武䮖照明光での三籼
激值を補正する。

（5）陚験照明光での，目標色の三刺激值と補正した 試料色の三刺激値を $\mathrm{L}^{*}, \mathrm{a}^{*}, \mathrm{~b}^{*}$ に変換して, 色 差 $J \mathrm{E}^{*}$ を計算する。

（6）その值を条件等色指数といい，Mで表す。

（7）条件等色指数は次のように表示する。

例 $1 . M\left(D_{65}: A\right)=2.0$

例 $2 . \mathrm{M}_{10}\left(\mathrm{D}_{65}: \mathrm{A}, \mathrm{F}_{6}\right)=(4.3,3.8)$

条件等色指数は，例えば， $\mathrm{M}_{10}\left(\mathrm{D}_{65}: \mathrm{A}\right)=5.2$ なら ば，目祭色と陚料色とを 10 度視野条件で，標準の光 $\mathrm{D}_{65}$ の下で茓全に出を 0 差合わせたとしても，標準 の光 $\mathrm{A}$ の下では色差が 5.2 程度発生するであろらとい 5意味の推定值である。

なお，武料照明光には標準の光Aのほかに，必要に 応じて，一般形白色虽光ランプ $\left(\mathrm{F}_{6}\right)$ ，演色改善形冝

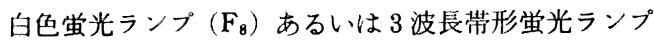
$\left(\mathrm{F}_{10}\right)$ などを用いることもある。詳しくは JIS Z 8719 （物体色の条件等色度の評価方法）を参照されたい。 最近の測色器械の中には，この評価計算のプログラム が組込まれている機種も市販されている。また，分光 父射辛の測定值があれば部算で求められる。

\section{5. 白さの評価}

紙などの白さを評㑑する方法に，例壳ば，ハンター 白色度などがある。

白さの棓価には心理的意義を主体にした方法と物理 的意義を主体にした方法とがある。

一般に，「白さ」の表現は心理的評洒尺度の用語と して使われることが多いが，ての中には「好ましい白 さ」の評価要絜が含まれているので，例えば，素材の 種類によって「白さ」の俥洒の仕方が異なってくる場 合もある2)。例えば，布地の白さと紙の白さを同列に 評価できないし，また，好ましい白さは時代と共に変 るかもしれない。

物理的な評価は光の反射率が高いものほど「白い」 として，規定照明における理想的白からの色差の大小 で比較する方法で，例えば次の(7)式で表わされる。

$$
\mathrm{W}=100-\Delta \mathrm{E}^{*}\left(\mathrm{~L}^{*}, \mathrm{a}^{*}, \mathrm{~b}^{*}\right)
$$

「白芯度」の評価方法にはこれら両者の意義を勘案 して作られたものも多い3。

例えば， $457.0 \pm 0.5 \mathrm{~nm}$ の 1 波長を採り，その波長 における文射竍を测定して白色度とする方法や次の(8) 式による方法なとがある。

$$
\mathrm{W}=4 \mathrm{~B}-3 \mathrm{Y}
$$


ここで， $\mathrm{B}=\mathrm{kZ}$ で， $\mathrm{Y}$ と $\mathrm{Z}$ は三刺激值である。な お， $\mathrm{k}$ は定数で，標準の光を用いるときは 0.847 を, キセノン標準白色光源を用いるときは 0.935 とする。

白色度を評価するに当たり，どのような方法を用い るかは当事者の間で定めるべきものであるが，評洒す る目的とデータの意味をよく理解して使うことが大切 である。特に，紙や布地の白さの評価の問題の中には 蛍光を含む場合と含まない場合とがあり，両者を同一 視して評価することは難しいので注意を要する。

周知のとおり，萤光色は短波長光を吸収して長波長 光で反射する性質があるから，分光した光を照明して その光の反射光を計测して为営光の性質を捉らえるこ とはできない。蛍光の性質を捉らえるためには柴外域 を含む慓準の光を照明し，蛍光色から反射された光を
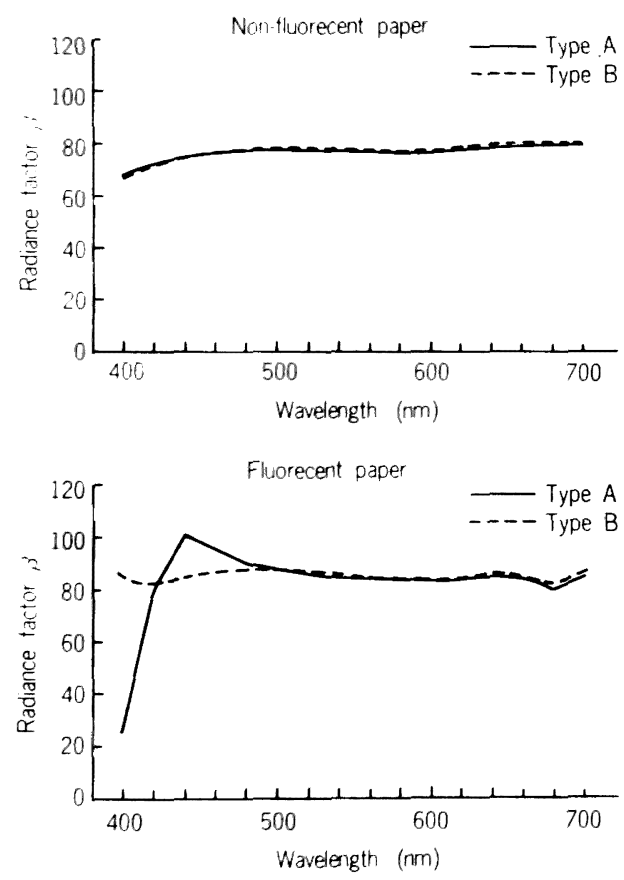

Fig. 6 Examples of the spectral radiance factor distributions measured a nonfluorescent paper and a fluorescent paper with different instruments.
分光して計測する必妿がある゙。しかし，現在では未 た検討中なので，蛍光色の测定方法は基本規格の JIS として制定されてはいない。

上記のよ5に光学系を変えた場合の測定事例の一つ として，蛍光を含まない上質紙と蛍光を含むカード紙 の分光測定結果を図6に示し参考に供する。

また、萤光を含む色と含まない色とを比較する場合 の部価方法の例 ‘次に兴げる。

$$
\begin{aligned}
\mathrm{W}= & 100-\left[\left(100-\mathrm{W}^{*}\right)^{2}\right. \\
& \left.+\left(\mathrm{U}^{*}-\mathrm{U}_{\mathrm{V}}^{*_{\mathrm{p}}}\right)^{2}+\left(\mathrm{V}^{*}-\mathrm{V}_{\mathrm{p}}\right)^{2}\right]^{1 / 2}
\end{aligned}
$$

ここで, U*, $\mathrm{V}^{*}, \mathrm{~W}^{*}$ は CIE(1967)UCS で, U* $=-5.59, \mathrm{~V}^{*}{ }_{\mathrm{p}}=-16.12$ である。

\section{6.あとがき}

この原稿は 1985 年 11 月 14 日に工業技術院筑波共 用講堂で行われた紙パルプ技術協会の年次大会で講演 した要旨を基にして，一部加筆し值して作成したもの である。当日はカラースライドを使って色の見え方の 説明もしたがここでは省略してある。また，紙面の都 合で要旨には掲载しなかった白さの評価方法について の事例を 2、3 加えた。

現在, 蛍光色の测定方法 ${ }^{6)}$ や白色度の評価方法の嫖 準化の見直しか゚なされつつあり，今後の研究成果に期 するところの方が大きいかもしれない忛れど，ご参考 に供する次第である。

文
1) 献
川:元郎：カラーマッチング入阴 (1970)

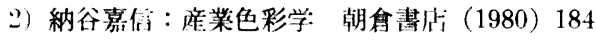

3）日本色彩学会編：新編色彩科学ハソドブック 東 大出版会（1980）289

4) D. B. Judd, G. Wyszecki : Color in Business Science and Industry John Wiley \& Sons (1975) 219

5）委員会解告：色科ニューズ 14 (1968) 26

6) 柇 礼於, 一条 隆: 日本色柇学会誌 9 (1985) 42 等 